\title{
Potential Factors to Enhance the Level of Disclosure within Financial Statements of Indonesian Provincial Governments
}

\author{
Johan Arifin \\ Accounting Department of Universitas Islam Indonesia \\ Email: johan.arifin@uii.ac.id
}

\begin{abstract}
Using Agency theory, this research aims to examine the factors that potentially influence the level of disclosure within financial statements in Indonesian provincial governments including Human Development Index (HDI), Liabilities, General Allocated Fund (GAF), and Provincial Original Revenue (POR). This research is very important because Indonesia has recently undergone major governmental financial reform and is seeking to greatly enforce its financial accounting transparency. The objects of this research are 99 financial statements from 33 Indonesian provinces in the period of 2014 to 2016. The level of disclosure is measured using a 34 item index derived from Indonesian Government Accounting Standards. Regression analysis shows that Human Development Index (HDI) and General Allocated Fund (GAF) are positive and significant predictors of the level of disclosure within financial statements of Indonesian provincial governments. These results can be used by Indonesian government as a potential information in making government policy related to financial transparency at provincial level.
\end{abstract}

Keywords: Level of disclosure; human development index; liabilities; general allocated fund; provincial original revenue

\section{INTRODUCTION}

Indonesia is an Asian developing country with a recent financial reformation to bring about good public governance. To attain the ultimate goal of good governance, the government persistently strives to boost transparency and accountability of financial management constituted of many aspects such as issuance of regulations, revamping the institutional system, and enhancing human resource quality. Indonesian Law on State Finance (Act No. 17 of 2003) requires the President, Governors, Regents and Mayors to submit accountability reports of the implementation of State/Regional Budget (APBN/APBD) in the form of financial statements covering at least Realization Report of APBN/APBD, Balance Sheet, Cash Flow Statement, and Notes on Financial Statements.

Various problems related to the existence of the financial statements are often the case, including those pinpointed by [34] as misstatement, manipulation, fraud, or misunderstanding. For this reason, there is an urge to standardize financial statements in an attempt to reduce those problems and to facilitate the inspection process. Therefore, in 2005, the Indonesian government issued Government Regulation No. 24 of 2005 on the Government Accounting Standards. Furthermore, in line with the current developments, the regulation has been completed with the issuance of [36].
In fact, there are different implementations of Government Accounting Standards by the provincial government in Indonesia. The difference can be seen from the opinions given by Indonesian $\mathrm{Su}$ preme Audit Board (BPK) in the Summary of Investigation Result (IHPS) on the first semester of 2017. The inspection results are presented in Table 1.

Table 1 pinpoints several things to improve. The potential occurrence of corruption is still high [24] as is evident from the actions of the Corruption Eradication Commission (KPK) which escorted the budget execution process of the six provinces in Indonesia [25] owing to their susceptibility for corruption. Additionally, the Audit Board of the Republic of Indonesia (BPK) stated that the governance of provincial financial statements still retain many problems.

The prevailing problems highlight the significance of transparency and accountability in financial management of the provincial government. Good transparency elucidates wide ranges of people about the government's financial statements. The more people know about this, the least the occurrence of various frauds since there are more parties taking a hard look on it.

Disclosure of financial statements is one form of transparency and accountability of government organizations [12] [31] [43] [47]. Knowing the potential factors affecting the level of disclosure of government financial statements will lead the information to be taken into consideration in 
Table 1. Financial Statements Opinion of the Indonesian Provincial Governments in 2010-2016

\begin{tabular}{|c|c|c|c|c|c|}
\hline Year & WTP & WDP & TW & TMP & Total \\
\hline 2010 & 6 & 22 & 0 & 5 & 33 \\
\hline 2011 & $\begin{array}{c}10 \\
30 \%\end{array}$ & $\begin{array}{c}19 \\
58 \%\end{array}$ & $\begin{array}{c}070 \\
0 \%\end{array}$ & $\begin{array}{c}1 \\
4 \\
12 \%\end{array}$ & $\begin{array}{c}33 \\
100 \%\end{array}$ \\
\hline 2012 & $\begin{array}{c}17 \\
52 \%\end{array}$ & $\begin{array}{c}11 \\
33 \%\end{array}$ & $\begin{array}{c}0 \\
0 \%\end{array}$ & $\begin{array}{c}5 \\
15 \%\end{array}$ & $\begin{array}{c}33 \\
100 \%\end{array}$ \\
\hline 2013 & $\begin{array}{c}16 \\
48 \%\end{array}$ & $\begin{array}{c}15 \\
45 \%\end{array}$ & $\begin{array}{c}0 \\
0 \% \\
\end{array}$ & $\begin{array}{c}2 \\
6 \%\end{array}$ & $\begin{array}{c}33 \\
100 \% \\
\end{array}$ \\
\hline 2014 & $\begin{array}{c}26 \\
74 \%\end{array}$ & $\begin{array}{c}7 \\
21 \% \\
\end{array}$ & $\begin{array}{c}0 \\
0 \%\end{array}$ & $\begin{array}{c}1 \\
3 \%\end{array}$ & $\begin{array}{c}34 \\
100 \%\end{array}$ \\
\hline 2015 & $\begin{array}{c}29 \\
85 \%\end{array}$ & $\begin{array}{c}5 \\
15 \%\end{array}$ & $\begin{array}{c}0 \\
0 \%\end{array}$ & $\begin{array}{c}0 \\
0 \%\end{array}$ & $\begin{array}{c}34 \\
100 \%\end{array}$ \\
\hline 2016 & $\begin{array}{c}31 \\
91 \%\end{array}$ & $\begin{array}{c}3 \\
9 \%\end{array}$ & $\begin{array}{c}0 \\
0 \%\end{array}$ & $\begin{array}{c}0 \\
0 \%\end{array}$ & $\begin{array}{c}34 \\
100 \%\end{array}$ \\
\hline
\end{tabular}

Legend: WTP=Unqualified Opinion; WDP=Qualified Opinion; TW=Adverse Opinion; TMP=Disclaimer of Opinion Source: Summary of [7].

making public policy and improvements as well as the future development associated with the transparency of financial statements.

There have been countless studies related to the level of disclosure of financial statements in various public sectors, especially in government sector. Some researches show that the age of the provincial government and provincial independence ratio affects the level of disclosure of financial statements [6] [18] [41] [44]. Meanwhile, the research conducted by [5] [16] [41] showed that the size of the legislature and the wealth of provincial governments also affects the level of disclosure of provincial government financial statements. Some other potential predictor variables such as Human Development Index (HDI), liabilities, funds transfer, population, area, the composition of the minority party, the amount of budget, quality auditor and others have been studied with varying results. Research on the potential factors affecting the level of disclosure of financial statements is yet to be developed since the Indonesian government still requires a lot of inputs to formulate public policies to boost the quality of financial statements of government agencies in Indonesia, especially that of provincial governments [3].

In this regard, this research uses the basic theory of agency to examine the potential factors that affect disclosure in the financial statements of the provincial government in Indonesia. According to [30] the agency problem is also common in government organizations. In a government organization, citizens act as the principal, while the government is the agent. Politicians can also be referred to as agents who oversee the performance of the government just like the citizens. However, politicians acted as agents of supervision as mandated by the citizens. In addition, [31] cited [28] that the relationship between the principal and agent can be seen in a political democracy. Society is the principal while politicians (the legislature) are the agent. This principal-agent relationship could be applied to different levels. In a lower level, politicians (the legislature) are the principal and bureaucrats (government officers) are the agent. In the next level, government officers could be the principal and employees are the agents.

Within the agency theory, management of accounting information is used for two purposes [38], including (1) for decision-making by the principal and the agent, (2) and for evaluating and sharing the results in accordance with employment contracts that have been made and approved. It may be referred to as the performance evaluation role to motivate the agent to take reasonable steps. According to [13], another form of agency theory in government is the national government as the principal and local government as an agent. The agency relationship leads to asymmetric information that brings some negative behaviors such opportunistic behavior, moral hazard and adverse selection [17].

Potential determinants of disclosure level of the financial statements of provincial governments include the following items. The first item is Human Development Index (HDI), used in previous studies to predict economic variables in government including the level of disclosure of financial statements [6] [11]. HDI is continuously used in a variety of development planning. The indicators used in Indonesia are the same as those used by the UNDP, except for the GNP per capita. This indicator is limited by per-capita spending.

Other items include obligations, the General Allocation Fund (GAF), and Provincial Original Revenue (POR). Some accounts show the relationship between the principal and the agent because 
there is liability provision from the other party. Principal for liability accounts are creditors or other parties. According to the [36], liabilities in the context of government occured as the use of loans from public sources of financing, financial institutions, other government entities, and international agencies as well as engagement with employees who work in the government or other service providers.

According to the [35] on Financial Balance between the Central Government and Local Government chapter 1 verse 21, it is stipulated that the General Allocation Fund (GAF) is a fund from APBN (State Budget) allocated for the purpose of equalization of financial capacity among the regions to finance regional needs in the implementation of decentralization or regional autonomy. The general allocation fund links provincial governments (i.e., agent) and the central government (i.e., principal) since General Allocation Fund (GAF) is one of the provincial government's transferred income. Local revenues, according to [35] chapter 1 verse 18 is a locally earned income levied by local regulations in accordance to the legislation.

Finally, Provincial Original Revenue (POR) is aimed at authorizing the local governments to fund the implementation of regional autonomy in accordance with the potential of the region as the embodiment of decentralization. Sources of revenue may take the form of local taxes, levies, wealth management outcomes separated areas and other legitimate Provincial Original Revenue (POR) [13]. Most sources primarily come from the public. Provincial Original Revenue (POR) sources enable the provincial government to act as an agent and the society as a principal.

Some prior studies using agency theory are [31] [44], as well as [41]. Within the concept of agency theory, good governance is pivotal to achieve. According to [27], good public governance is also referred to as clean government. Good governance consists of five aspects, such as transparency, accountability, responsiveness, independence, and fairness [22] and [21].

\section{Research Hypothesis}

\section{Human Development Index (HDI)}

The financial statements require disclosure both to support accountability and transparency in accordance with the principles of good governance. Users of financial statements of provincial government is the community whose quality is represented by the Human Development Index (HDI) [42]. The higher the education level of the community is, the higher their awareness of information is. Therefore, such community will require higher demand for disclosure of financial statements. [39] argues that human qualities greatly affect economic performance. Further, it is revealed that when human resources are well developed, the regional economic performance will increase.

Previous research conducted by [4] and [33] indicated that social surveillance positively affects the performance of governance. The research correlate social surveillance with the levels of public education as seen through the HDI. Meanwhile, [29] conducted a research on the influence of human capital on the performance of financial and non-financial companies. Human capital consists of the existence of training, education, knowledge and skills. The results of these studies indicate that human capital are closely associated with some economic fundamentals and company performance. Other studies on HDI conducted by [1] and [39] pinpoint that human development influences the economic performance. The economic performance is generally expressed in the form of financial statements.

On the basis of the previous discussion, the first research hypothesis is as follows:

H1: HDI positively affects the level of disclosure of provincial government financial statements in Indonesia.

\section{Liability}

Liability is the duty or responsibility to other parties to transfer some financial resources, which shows the relationship between the government and other parties [46]. [36] stipulated that users of government's financial statements include parties that donate, invest, or provide loans. The higher the liability is, the more accountable the management is and that ultimately requires local government to improve the quality level of disclosure in financial statements. Therefore, the local government is likely to provide comprehensive information in its financial statements to eliminate the doubts of creditors against the fulfillment of their rights [44].

Given such explanation, the second hypothesis can be formulated as follows:

H2: Liabilities positively affect the level of disclosure of provincial government financial statements in Indonesia.

\section{General Allocation Fund (GAF)}

General Allocation Funds (GAF) are funds allocated to local governments to equalize fiscal capacity among regions [35]. Research [5] and [31] highlighted that the higher the GAF received by local authority, the higher the pressure on local governments to comply with regulations. General 
Allocation Fund (GAF) shows the dependence level of the local governments on the central government [15]. Thus, if the value of GAF of a province is high, the pressure of the central government to the provinces will be higher as well. Consequently, this requires that the province improves the operational and financial statements accountability to the central government.

According to [2], transferred income consists of the equalization funds, other central transferred income and other legitimate transferred income. In Indonesia, the General Allocation Fund (GAF) is part of the balance funds. Furthermore, [44] suggested that the local government try to account for the use of revenue transfers to finance local government spending. This is conducted as a form of transparency and accountability in financial management. In connection with this, it is possible that the greater the revenue transfer is, the greater the level of disclosure of the financial statements is. The third hypothesis is as follows:

H3: General Allocation Fund (GAF) positively affects the level of disclosure of provincial government financial statements in Indonesia.

\section{Provincial Original Revenue (POR)}

[48] states that the Provincial Original Revenue (POR) reflects the performance of the region to generate revenue independently. An area that has high POR will disclose to stakeholders that the local government has been working hard in order to obtain high performance. This disclosure provides a signal of good public management [26]. Therefore, the POR is likely associated with higher level of disclosure in the financial statements by provincial governments.

Research conducted by [41] as well as [19] shows that regional wealth proxied through POR has a positive effect on the level of local government financial statement disclosure. It is necessary to investigate this further in order to examine the impact of the Provincial Original Revenue (POR) on the level of provincial government financial statement disclosure. Therefore, the research hypothesis is formulated as follows:

H4: Provincial Original Revenue (POR) positively affects the level of disclosure of provincial government financial statements in Indonesia.

\section{RESEARCH METHOD}

The research population was the whole Provincial Government Financial Statements in Indonesia that has been audited by the Indonesian
Supreme Audit Board (BPK). Data for the study were taken from 33 provinces in Indonesia during the period of 2014 to 2016 . Total financial statements that were studied were 99 reports. Financial statements data were obtained from audit reports of Indonesian Supreme Audit Board (BPK).

\section{Measurement Techniques}

The dependent variable in this study is the level of disclosure of financial statements of the provincial government in Indonesia. This variable is measured through an assessment derived from the Notes to Financial Statements (CALK) with an index scoring method, which uses a score revelation of CALK in accordance with [36] concerning the Government Accounting Standards (SAP) Statement No. 04 (Annex I.05 PSAP 04). The provisions in these rules are summarized in 34 disclosure items. The method gives a value of one (1) for each item disclosed in every year and a value of zero (0) for items that are not disclosed. This method was used in previous studies. such as [6]; [9]; and [32]. The total score was divided by the total expected score.

$$
\text { The level of disclosure }=\frac{\text { Disclosed Items }}{\text { Items to be disclosed }}
$$

The independent variables in this study include four items as follows.

1. Human Development Index (HDI). It was formed through a three-dimensional approach foundation, including longevity and healthy life, knowledge and a decent standard of living [8]. Data about the HDI are obtained from the Central Statistics Agency (BPS).

2. Liabilities. The liabilities make the government interacts with other parties, mainly the creditors. Data of liabilities of every province were derived from the Central BPK.

3. General Allocation Fund (GAF). [35], it is stipulated that the GAF can be defined as the funds allocated to local governments that aims to equalize fiscal capacity among regions, while GAF is part of the balance funds transferred from the central government. The value of GAF was obtained from the Budget Realization Report derived from the Central BPK.

4. Provincial Original Revenue (POR). The enactment of the regional autonomy of law requires all regions to carry out all administrative matters and development by relying on Provincial Original Revenue (POR) they possess [50]. Furthermore [2] argued that the ability of an area to generate POR will affect the development and advancement of a region. 


\section{RESULTS AND DISCUSSION}

The descriptive s presented in the following table 2 .

Table 2. Results of Descriptive Statistic

\begin{tabular}{|c|c|c|c|c|c|c|c|}
\hline & \multirow{2}{*}{$\begin{array}{c}\mathrm{n} \\
\text { Statistic }\end{array}$} & \multirow{2}{*}{$\begin{array}{l}\text { Minimum } \\
\text { Statistic }\end{array}$} & \multirow{2}{*}{$\begin{array}{l}\text { Maximum } \\
\text { Statistic }\end{array}$} & \multirow{2}{*}{$\begin{array}{c}\text { Sum } \\
\text { Statistic }\end{array}$} & \multicolumn{2}{|c|}{ Mean } & \multirow{2}{*}{$\begin{array}{l}\text { Std. Deviation } \\
\text { Statistic } \\
\end{array}$} \\
\hline & & & & & Statistic & Std. Error & \\
\hline CALK & 99 & .265 & .9120 & 64.028 & .646 & .012741 & .126770 \\
\hline HDI & 99 & 55.550 & 78.390 & 6673.040 & 67.404 & .42807 & 4.25927 \\
\hline LnLiabilities & 99 & 16.550 & 30.170 & 2527.0 & 25.525 & 19455 & 1.93576 \\
\hline LnGAF & 99 & 24.690 & 28.320 & 2716.180 & 27.436 & .06377 & .63446 \\
\hline LnPOR & 99 & 25.480 & 31.070 & 2766.720 & 27.946 & .12704 & 1.26400 \\
\hline Valid N (listwise) & 99 & & & & & & \\
\hline
\end{tabular}

Information: CALK (Notes on Financial Statements), HDI (Human Development Index), LnLiabilities (Liabilities in Natural Logarithm), LnGAF (General Allocation Fund in Natural Logarithm), LnPOR (Provincial Original Revenue in Natural Logarithm).

Source: Processed SPSS Data Output 2017.

In Table 2, the value of $\mathrm{n}$ indicates the amount of data that is 99 financial statements. The lowest value of CALK was 0.265 for the West Papua province in 2016, while the highest value of CALK was 0.912, obtained by the East Java province in 2016. The average value of CALK was 0.646 with a standard deviation of 0.126770 , suggesting that the rate of data dissemination size was 0.126770 .

In 2014, the West Papua Province had the lowest HDI of 55.55 and Jakarta has the highest HDI of 78.390. The standard deviation of HDI was 4.25927 which, suggesting that the data dissemination was at 4.25927 with the average value of 67.4044.

In 2014 the highest liability was obtained by Riau province that is equal to 30.170 in natural logarithm and amounted 126,870,188,108,064 in rupiah. As for the minimum liability with 16.550 in the natural logarithm was obtained by Central Kalimantan Province in 2014 with a value of $15,453,227$ in rupiah. The average value of the liability in the natural logarithm was 25.5253 with a standard deviation of 1.93576 and the mean value of data dissemination of 1.93576 .

In 2014, the East Kalimantan province has the lowest value of 24.690 in Government Allocation Fund (GAF) (measured in natural logarithm), amounting to 52,637,761,000 in rupiahs. The highest value of GAF is reported by the Province of Papua in 2016 with a value of 28.320 in natural logarithm, amounting to 1.991.202.341.100 in rupiahs. The average value of GAF in natural logarithm was of 27.4361 with a standard deviation of 0.63446 , which means that the data dissemination was at 0.63446 .

The province with the highest revenue (POR) is Jakarta, amounting to 31.070 in natural logarithm, equal to Rp. $31,274,215,885,719$. The North Maluku Province had the lowest revenue of 25.480 in natural logarithm or Rp. 115,905,322,981.68. The standard deviation of Provincial Original Revenue (POR) in natural logarithm was of 1.26400 , which means that the dissemination value was of 1.26400. The average value of POR in natural logarithm was of 27.9467.

\section{Multiple Regression Analysis}

In this study, the variables in the rupiah are transformed into natural logarithms to facilitate the processing of data using SPSS software. The regression equation is systematically formulated as follows:

CALK $=\alpha+\beta_{1} \mathrm{HDI}+\beta_{2}$ LnLiabilities $+\beta_{3} \operatorname{LnGAF}+$ $B_{4} \operatorname{LnPOR}+\mathrm{e}$

Information:

CALK $=$ Notes to the Financial Statements

a $=$ Constanta

B $\quad=$ Coefficient

HDI $\quad=$ Human Development Index

LnLiabilities $=$ Liabilities in the Natural Logarithm

LnGAF $=$ General Fund Allocation in the Natural Logarithm

LnPOR = Locally-Generated Revenue in the Natural Logarithm

e $\quad=$ error term

\section{Hypothesis testing}

1. Table 3 below describes the coefficient determination of the regression model.

Table 3. Results of Coefficient Determination

\begin{tabular}{ccrrrr}
\hline Model & $\mathrm{R}$ & $\begin{array}{c}\mathrm{R} \\
\text { Square }\end{array}$ & $\begin{array}{r}\text { Adjusted } \\
\mathrm{R} \text { Square }\end{array}$ & $\begin{array}{c}\text { Std. Error of } \\
\text { the Estimate }\end{array}$ & $\begin{array}{l}\text { Durbin- } \\
\text { Watson }\end{array}$ \\
\hline 1 & $.508^{\mathrm{a}}$ & .258 & .226 & .111528 & 2.000 \\
\hline
\end{tabular}

a. Predictors: (Constant), LnPOR, LnGAF, LnLiabilities, HDI

b. Dependent Variable: CALK

Source: Processed Data Output of SPSS 2017 
Adjusted $\mathrm{R} 2$ value is 0.226 , meaning that $22.6 \%$ of the variation rate of the disclosure of financial statements can be explained by the variation of the four independent variables, namely HDI, liabilities, GAF and POR. The rest (77.4\%) is explained by other factors outside the model.

2. Significant Parameter Individual Test (Test Statistic-t)

Table 4 below describes the $\mathrm{t}$ statistical test results of this study.

Based on Table 4, it can be seen that of the four predictor variables included in the regression model, HDI variables and the General Allocation Fund (GAF) significantly affect the level of disclosure of financial statements in Indonesian provincial governments. The other variables, namely the liabilities and Provincial Original Revenue (POR), do not affect the level of disclosure of provincial government financial statements in Indonesia.

Effect of Human Development Index (HDI) on the Level of Financial Statements Disclosure for the Provincial Governments in Indonesia

The results of this study indicate that HDI value is associated with the level of financial statement disclosure. These results are in line with the previous studies conducted by [1]; [4]; and [29]. Furthermore, [1] in his research reveals that an area with high human development quality will have an increasing level of economic performance, and the area will be more developed than other regions. It is based on the premise that good economic performance will boost the spirit of local governments to disclose their performance in their financial statements. Communities with better level of education and prosperity will be more aware of the information and the rights and liabilities of their government [14]. In addition, people will also have higher awareness to monitor governmental performance.
In line with this, [4] state that public participation is highly pivotal because the forms of autonomy and decentralization must put forth the aspirations and interests of the community as top priority. Communities with adequate level of education will have a high participation in government control [10]. Given the high community participation, the process of autonomy and decentralization will be well implemented more smoothly so that public participation in monitoring the course of the regional government will also increase. As a result, this will require the local governments to be more careful in running the government and more accountable in reporting its financial results in the form of financial statements with a complete disclosure.

\section{Effect of Liabilities on the Level of Financial Statements Disclosure for the Provincial Governments in Indonesia}

The results are consistent with the research conducted by [44] which highlights that liabilities do not significantly affect the level of disclosure in the financial statements of the local government. The other study conducted by [49] also reveals that the leverage ratio obtained by dividing total debt by total asset do not affect the level of disclosure in the financial statements of local government. Similar results were also shown by [20] stating that a leverage ratio proxied through a debt equity ratio also showed no significant effect on the level of disclosure of financial statements.

[20] argues that greater amount of liabilities is associated with more information disclosed on the use of debt to stakeholders. As a result, organizations are required to do more extensive disclosure in its financial statements. The requirement to disclose more on liabilities usually avoided by local government due to their complex work load. The creditor may use other information outside financial statements as a consideration to credit, such as credit history, credit guarantee, the local reputation, and others.

Table 4. Multiple Regression Analysis

\begin{tabular}{|c|c|c|c|c|c|c|c|c|}
\hline & \multirow{2}{*}{ Model } & \multicolumn{2}{|c|}{$\begin{array}{c}\text { Unstandardized } \\
\text { Coefficients }\end{array}$} & \multirow{2}{*}{$\begin{array}{c}\text { Standardized } \\
\text { Coefficients }\end{array}$} & \multirow[t]{2}{*}{$\mathrm{T}$} & \multirow{2}{*}{ Sig. } & \multicolumn{2}{|c|}{ Collinearity Statistics } \\
\hline & & $\mathrm{B}$ & Std. Error & & & & Tolerance & VIF \\
\hline \multirow[t]{5}{*}{1} & (Constant) & -1.790 & .674 & & -2.656 & .009 & & \\
\hline & HDI & .015 & .004 & .511 & 4.026 & .000 & .490 & 2.039 \\
\hline & LnLiabilities & .011 & .007 & .175 & 1.608 & .111 & .664 & 1.506 \\
\hline & LnGAF & .042 & .020 & .212 & 2.084 & .040 & .765 & 1.308 \\
\hline & LnPOR & -.001 & .013 & -.015 & -.111 & .912 & .438 & 2.285 \\
\hline
\end{tabular}

Dependent Variable: CALK

Source: Processed Output Data of SPSS 2017 


\section{Effect of General Allocation Fund (GAF) on The Level of Financial Statements for the Provincial Governments in Indonesia}

The result supports the study conducted by [37] as well as [45] which show that the GAF has a positive impact on the level of disclosure in the financial statements of local governments. However, these results are not consistent with studies conducted by [19] as well as [44] where the GAF had no significant effect on the level of disclosure in the financial statements as shown through the government agencies' website.

[31] revealed that the higher the GAF, the higher the pressure on a government to comply with regulations. In this case, GAF shows the level of dependency of the provincial governments on the central government. The province with a high degree of dependency on central government funding sources will have high pressure to disclose more information in its financial statements [37]. Besides, the disclosure is a form of transparency and accountability so that the government can try to account for the use of funds from the central government [44]. The high General Allocation Fund (GAF) makes the provincial government compelled to express its use in order to maintain the trust of the central government. In other words, high GAF reflects the high use of funds, encouraging greater disclosure in financial statements.

\section{Effect of Provincial Original Revenue (POR) on the Level of Financial Statements Disclo- sure for the Provincial Governments in Indonesia}

The results of this study are not consistent with the results of the study by [41] as well as [19], which revealed that the regional wealth proxied through POR have a positive effect on the level of local government financial statement disclosure.

The result of the study by [23] revealed that the POR variable does not affect the level of disclosure in the financial statements of local governments. The low level of public concern over new taxes and fees to be paid to the government may provide a potential explanation for the result. There are still many taxpayers who do not pay taxes, thus resulting in lower revenue. This is due to the weak enforcement in tax payment and the mild sanction to those evading tax payment. The low awareness of tax payment responsibility is also due to the knowledge about the complexity of the tax administration and tax payments. Despite paying taxes, taxpayers are less likely to demand their rights in terms of getting information for any taxes paid.

\section{CONCLUSION}

The purpose of this study is to obtain empirical evidence influencing several potential factors including the Human Development Index (HDI), liabilities, General Allocation Fund (GAF), and Provincial Original Revenue (POR) to the level of disclosure of financial statements of Indonesian provincial governments. Regression analysis shows that the Human Development Index (HDI) positively affect the level of disclosure of financial statements. It is possible that people with high levels of education and a prosperous life are more aware of the information, the rights and liabilities of the government. This encourages the community to participate in monitoring the performance of government.

Furthermore, the results of hypothesis testing show that liabilities do not affect the level of disclosure of financial statements of the provincial governments in Indonesia. This is possible because the financial statements of the provincial governments in Indonesia do not focus on disclosure obligations in particular, but more focus on the overall performance.

Results of the regression analysis in this study also show that the General Allocation Fund (GAF) positively affects the level of disclosure of financial statements of the provincial governments in Indonesia. The high General Allocation Fund (GAF) has compelled the provincial governments to increase disclosure in order to maintain trust from the central government.

Finally, it was revealed that the Provincial Original Revenue (POR) does not significantly affect the level of disclosure of financial statements of the provincial governments in Indonesia. This is possible because there is a lack of public awareness to pay taxes so that there is no certainty in estimated local revenues every year. As a consequence, POR does not affect the decision of local governments to clearly present and disclose their financial statements. In addition, it may also be attributed to low demand of transparency in the society.

\section{REFERENCES}

[1] Amaliah, I. 2006. The influence of human development on the economic performance of Indonesian local governments. Mimbar, 22 (2): 213-233.

[2] Andirfa, M., Basri. H. dan Majid. M.S.A. 2016. The effect of capital expenditure, fiscal balance funds, and local own revenue toward financial performance of Indonesian local Governments. Jurnal Administrasi Akuntansi, 5(3): 30-38. 
[3] Anggraeni, D.T. 2014. Factors affecting the reliability of financial reporting of local Government: The case study of the district of Sidoarjo, East Java. Jurnal Ilmu dan Riset Akuntansi, 3(3): 1-16.

[4] Arifianti, Payamta dan Sutaryo. 2013. The influence of controlling and monitoring of local finance toward the performance of local government administration (Empirical studies on the government of districts/cities in Indonesia). Simposium Nasional Akuntansi XVI Manado, 25-28 September 2013.

[5] Arifin, J., Tower. G. and Porter. S. 2013. Fiscal Policy Disclosure in Indonesian Local Government. Jurnal Akuntansi dan Auditing Indonesia. 17(1): 13-30.

[6] Arifin, J., Tower. G. and Porter. S. 2015. Financial reporting compliance in Indonesian local government: Mimetic pressure dominates. Jurnal Akuntansi dan Auditing Indonesia, 19(1): 68-83.

[7] Badan Pemeriksa Keuangan Republik Indonesia (BPK-RI). 2015. IHPS 1 Tahun 2015. Jakarta.

[8] BPS. 2015. Indeks Pembangunan Manusia 2014 Metode Baru. Jakarta.

[9] Cooke, T.E., 1991. An assessment of voluntary disclosure in annual reports of Japanese corporations. The International Journal of Accounting 26(3): 147-189.

[10] Cummings, W.K. and Riddell. A. 1994. Alternative policies for the finance, control, and delivery of basic education. International Journal of Educational Research, 21(8): 751-776.

[11] Dagiliene, L. 2010. The research of corporate social responsibility disclosures in annual reports. Engineering Economics, 21(2): 197-204.

[12] Dhaliwal, D., Lie. O.Z., Tsang. A., and Yang. Y.G. 2014. Corporate social responsibility disclosure and the cost of equity capital: The roles of stakeholder orientation and financial transparency. Journal of Accounting and Public Policy, 33(4): 328-355.

[13] Fadzil, F., Hanim dan Nyoto. H. 2011. Fiscal decentralization after implementation of local government autonomy in Indonesia. World Review of Business Research, 1(2): 51-70.

[14] Ferlie, E., Musselin. C. and Andresani. G. 2008. The steering of higher education systems: a public management perspective. Higher Education, 56: 121-133.

[15] Harahap, R.U. 2011. The influence of general allocation fund, special allocation fund, and fiscal balance fund toward human development index in Indonesian local Governments. Jurnal Riset Akuntansi dan Bisnis, 11(1): 4758.
[16] Hix, S. 2004. Electoral institutions and legislative behavior: Explaining voting defection in the European parliament, World Politics 56 (2): 194-223.

[17] Hoenen, A.K. and Kostova. T. 2014. Utilizing the broader agency perspective for studying headquarters-subsidiary relations in multinational companies. Journal of International Business Studies, 46(1): 104-113.

[18] Hossain, S. 2008. Rapid urban growth and poverty in Dhaka city. Bangladesh e-Journal of Sociology, 5(1): 1-24.

[19] Jaya, J. D. dan Sisdyani. E.A. 2014. The influence of local own revenue, general allocation fund, and capital expenditure on the completeness of financial information disclosure through the provincial official website. $E$ Jurnal Akuntansi Universitas Udayana, 9(2): 285-303.

[20] Kartika, A. dan Hersugondo. 2009. Factors affecting the completeness of the disclosure of financial statements. Ekspansi, 4(7): 44-59.

[21] Keban, 2000. 'Good governance' dan 'capacity building' sebagai indikator utama dan fokus penilaian kinerja pemerintahan. Jurnal Naskah 20(1): 1-12.

[22] Kent, P. and Stewart. J. 2008. Corporate governance and disclosures on the transition to international financial reporting standards. Accounting and Finance 48(4): 649-671.

[23] Khasanah, N.L. dan Rahardjo. S.N. 2014. The influence of characterictics, complexity, and audit findings toward local government performace. Diponegoro Journal of Accounting, 3(3): 1-11.

[24] Koroy, T.R. 2008. Pendeteksian kecurangan (fraud) laporan keuangan oleh auditor eksternal. Jurnal Akuntansi dan Keuangan, 10(1): 22-33.

[25] KPK. 2016. KPK bentuk satuan tugas terpadu di 6 provinsi. http://www.kpk.go.id/id/ berita/berita-sub/3378-kpk-bentuk-satuantugas-terpadu-di-6-provinsi. (Accessed: June 15, 2017).

[26] Latridis, G.E. 2013. Environmental disclosure quality: Evidence on environmental performance, corporate governance and value relevance. Emerging Markets Review, 14(1): 5575.

[27] Mahmudi. 2013. Akuntansi Sektor Publik. Yogyakarta: UII Press.

[28] Mahoney, P.G. 1995. Mandatory disclosure as a solution to agency problems. The University of Chicago Law Review, 62(3): 1047-1112.

[29] Marimuthu, M., Arokiasamy. L, dan Ismail. M. 2009. Human capital development and its impact on firm peformance: Evidence from 
developmental economics. The Journal of International Social Research, 2(8): 256-272.

[30] Martani. D. and Hilmi. 2012. Analysis of factors affecting the level of disclosure of the local government financial statements. Simposium Nasional Akuntansi XV Banjarmasin, 20 - 22 September 2012.

[31] Martani, D. dan Lestiani. 2012. Disclosure in local government financial statements: The case of Indonesia. Global Review of Accounting and Finance, 3(1): 67-84.

[32] Meek, G.K., Roberts and Gray. C.B. 1995. Factors influencing voluntary annual reports disclosure by US, UK and continental European multinational corporations. Journal of International Business Studies, 26(3): 555572.

[33] Nurhayati, R., Brown. A.M. and Tower. G. 2006. Understanding the level of natural environmental disclosures by Indonesian listed companies. Journal of the Asia Pasific Centre for Environmental Accountability, 12(3): 4-11.

[34] Olajumuke, J. 2010. Effect of globalization on financial reporting: A case study of Zenith bank PLC. Social Science Research Network, from http://dx.doi.org/10.2139/ ssrn.2146570 (Accessed: March 15, 2017).

[35] Pemerintah Republik Indonesia. 2004. UU No. 33 tahun 2004 tentang Perimbangan Keuangan antara Pemerintah Pusat dan Pemerintah Daerah. Jakarta.

[36] Pemerintah Republik Indonesia. 2010. PP No. 71 Tahun 2010 tentang Standar Akuntansi Pemerintah. Jakarta.

[37] Puspita, R. dan Martani. D. 2012. Analisis Pengaruh Kinerja dan Karakteristik Pemda Terhadap Tingkat Pengungkapan dan Kualitas Informasi Dalam Website Pemda. Simposium Nasional Akuntansi XV Banjarmasin, 20 - 22 September 2012.

[38] Puyvelde, S.V., Caers. R., Bois. C.D. and Jegers. M. 2011. The governance of nonprofit organizations: Integrating agency theory with stakeholder and stewardship theories. Nonprofit and Voluntary Sector Quarterly, 41(3): 431-451.

[39] Ravallion, M. 2011. The Human Development Index: A response to Klugman, Rodriguez, and Choi, Journal Economic In Equa.l 9(1): 475-478.
[40] Ravallion, M. 2012. Troubling trade offs in the Human Development Index. Journal of Development Economics, 99(2): 201-209.

[41] Setyaningrum, D. dan Syafitri. F. 2012. The effect of local government characteristics towards the level of disclosure of financial statements. Jurnal Akuntansi dan Keuangan Indonesia, 9(2): 154-170.

[42] Spangenberg, J.H. 2015. The Corporate Human Development Index CHDI: A tool for corporate social sustainability management and reporting. Journal of Cleaner Production, 134(1): 414-424.

[43] Stefanescu, C.A. 2011. Disclosure and transparency in corporate governance codes-comparative analysis with prior literature findings. Procedia Social and Behavioral Sciences, 24: 1302-1310.

[44] Suhardjanto, D. dan Lesmana. S.I. 2010. The effect of local government characteristics on the level of mandatory disclosure of Indonesian local governments. Prestasi, 6(2): 25-40.

[45] Sulistyaningsih dan Gunawan. B. 2016. Analysis of factors affecting risk management disclosure. Jurnal Riset Akuntansi dan Keuangan Indonesia, 1(1): 5-22.

[46] Suwardjono, 2006. Teori Akuntansi Perekayasaan Pelaporan Keuangan. Edisi Ketiga. BPFE: Yogyakarta.

[47] Tagesson, T., Klugman. M, and Ekstrom. M.L. 2011. What explains the extent and content of social disclosure in Swedish Municipalities' annual reports. Journal of Management and Governance, 17(2): 217-235.

[48] Tuasikal, A. 2007. Pengaruh pemahaman sistem akuntansi, pengelolaan keuangan daerah terhadap kinerja satuan kerja pemerintah daerah (Studi pada Kabupaten Maluku Tengah di Provinsi Maluku). Jurnal Akuntansi Dan Keuangan Sektor Publik. 8(1): 146168.

[49] Waliyyani, G. M. dan Mahmud. A. 2015. The influence of local government characteristics toward the level of disclosure within financial statements of Indonesian local government. Accounting Analysis Journal. 4(2): 46-61.

[50] Wenny, C.D. 2012. The influence of Local Own Revenue (LOR) towards the financial performance of South Sumatra province. Jurnal Ilmiah STIE MDP, 4(1): 39-51. 